\title{
Osteopathia striata-pigmentary dermopathy-white forelock syndrome
}

INSERM

\section{Source}

INSERM. (1999). Orphanet: an online rare disease and orphan drug data base.

Osteopathia striata-pigmentary dermopathy-white forelock syndrome. ORPHA:2779

Osteopathia striata-pigmentary dermopathy-white forelock syndrome is characterised by the association of osteopathia striata (longitudinal striations through most of the long bones) with a macular, hyperpig mented dermopathy and a white forelock. 